\title{
Kinetic and Theoretical Studies on Pyridinolysis of 2,4-Dinitrophenyl X-Substituted Benzoates: Effect of Substituent $X$ on Reactivity and Mechanism
}

\author{
Ik-Hwan Um, ${ }^{*}$ Eun-Hee Kim, Li-Ra Im, and Masaaki Mishima ${ }^{\dagger}$
}

\author{
Department of Chemistry and Nano Science, Ewha Womans University, Seoul 120-750, Korea. E-mail: ihum@ewha.ac.kr \\ ${ }^{\dagger}$ Institute for Materials Chemistry and Engineering, Kyushu University, Hakozaki, Higashi-ku, Fukuoka 812-8581, Japan \\ Received July 6, 2010, Accepted July 26, 2010
}

\begin{abstract}
Second-order rate constants $\left(k_{\mathrm{N}}\right)$ have been measured spectrophotometrically for reactions of 2,4-dinitrophenyl $\mathrm{X}$-substituted benzoates $\left(\mathrm{X}=4-\mathrm{MeO}, \mathrm{H}\right.$ and $4-\mathrm{NO}_{2}$ ) with a series of $\mathrm{Z}$-substituted pyridines in $80 \mathrm{~mol} \% \mathrm{H}_{2} \mathrm{O} / 20 \mathrm{~mol}$ $\%$ DMSO at $25.0 \pm 0.1{ }^{\circ} \mathrm{C}$. The Brønsted-type plots exhibit downward curvature (e.g., $\beta_{2}=0.89 \sim 0.96$ when p $K_{\mathrm{a}}<$ 9.5 while $\beta_{1}=0.38 \sim 0.46$ when $\mathrm{p} K_{\mathrm{a}}>9.5$ ), indicating that the reaction proceeds through a stepwise mechanism with a change in rate-determining step (RDS). The $\mathrm{p} K_{\mathrm{a}}^{\mathrm{o}}$, defined as the $\mathrm{p} K_{\mathrm{a}}$ at the center of Brønsted curvature, has been analyzed to be 9.5 regardless of the electronic nature of the substituent $\mathrm{X}$ in the benzoyl moiety. Dissection of $k_{\mathrm{N}}$ into the microscopic rate constants $k_{1}$ and $k_{2} / k_{-1}$ ratio has revealed that $k_{1}$ is governed by the electronic nature of the substituent $\mathrm{X}$ but the $k_{2} / k_{-1}$ ratio is not. Theoretical calculations also support the argument that the electronic nature of the substituent $\mathrm{X}$ in the benzoyl moiety does not influence the $k_{2} / k_{-1}$ ratio.
\end{abstract}

Key Words: Pyridinolysis, Brønsted-type plot, Intermediate, Rate-determining step, Reaction mechanism

\section{Introduction}

Aminolyses of carboxylic esters have been reported to proceed either through a concerted mechanism or through a stepwise mechanism depending on reaction conditions (e.g., nature of amines, structure of esters, solvents, etc.). ${ }^{1-15}$ Curved Brønsted-type plots reported for aminolyses of esters possessing a weakly basic leaving-group (e.g., 2,4-dinitrophenoxide) have been taken to be diagnostic of a change in rate-determining step (RDS). ${ }^{1-7}$ It has been proposed that RDS changes at $\mathrm{p} K_{\mathrm{a}}^{\mathrm{o}}$, defined as the $\mathrm{p} K_{\mathrm{a}}$ at the center of Brønsted curvature. ${ }^{4,5}$ It is now firmly understood that RDS is dependent on the basicity of the incoming amine and the leaving group, i.e., it changes from breakdown of a zwitterionic tetrahedral intermediate $\mathrm{T}^{ \pm}$to its formation as the amine becomes more basic than the leaving group by 4 to $5 \mathrm{p} K_{\mathrm{a}}$ units.

However, the effect of substituents in the nonleaving group on reaction mechanism is not clearly understood. It has been reported that $\mathrm{p} K_{\mathrm{a}}^{\mathrm{o}}$ increases as the substituent in the nonleaving group changes from an electron donating group (EDG) to an electron withdrawing group (EWG) for reactions of diaryl carbonates with quinuclidines in $\mathrm{H}_{2} \mathrm{O}$. ${ }^{4}$ A comparable result has been reported for pyridinolysis of 2,4-dinitrophenyl X-substituted benzoates in $44 \%$ aqueous ethanol (i.e., $\mathrm{p} K_{\mathrm{a}}^{\mathrm{o}}=9.5$ when $\mathrm{X}=\mathrm{H}$ but $\mathrm{p} K_{\mathrm{a}}^{\mathrm{o}}>9.5$ when $\mathrm{X}=4-\mathrm{Cl}$ and $\left.4-\mathrm{NO}_{2}\right) .{ }^{5}$ Besides, $\mathrm{p} K_{\mathrm{a}}{ }^{\mathrm{o}}$ for aminolysis of $S$-2,4-dinitrophenyl X-substituted thiobenzoates has been reported to increase from 8.5 to 8.9 and 9.9 as $\mathrm{X}$ changes from 4-Me to $\mathrm{H}$ and $4-\mathrm{NO}_{2}$, respectively. ${ }^{6}$ This has been explained through the argument that an EWG in the nonleaving group retards expulsion of the leaving group from $\mathrm{T}^{ \pm}$ (the $k_{2}$ process) but accelerates departure of the amine (the $k_{-1}$ process) as the substituent in the nonleaving group becomes a stronger EWG. ${ }^{4-6}$ Accordingly, it has been concluded that the $k_{2} / k_{-1}$ ratio decreases as the substituent in the nonleaving group changes from an EDG to an EWG, and the decreased $k_{2} / k_{-1}$ ratio is responsible for the increase in $\mathrm{p} K_{\mathrm{a}}^{\mathrm{o}}$.
In contrast, we have shown that $\mathrm{p} K_{\mathrm{a}}^{\mathrm{o}}$ and $k_{2} / k_{-1}$ ratio are not influenced by the electronic nature of substituent $\mathrm{X}$ in the nonleaving group for pyridinolysis of $O$-4-nitrophenyl X-substituted thionobenzoates ${ }^{3}$ and aminolysis of 2,4-dinitrophenyl X-substituted benzenesulfonates in $80 \mathrm{~mol}_{\%} \mathrm{H}_{2} \mathrm{O} / 20 \mathrm{~mol}_{\%} \mathrm{DMSO}^{7 \mathrm{a}}$ It has been found that the Hammett plots for these reactions are not linear, e.g., the $\rho$ value decreases as the substituent changes from EDGs to EWGs. Such curved Hammett plots have traditionally been interpreted as a change in RDS. However, it has been concluded that the nonlinear Hammett plots are not due to a change in RDS since the corresponding YukawaTsuno plots exhibit excellent linear correlations with large $r$ values. $^{3,7 \mathrm{a}}$

We have recently reported that pyridinolysis of 2,4-dinitrophenyl benzoate (1b) proceeds through a stepwise mechanism with a change in RDS. ${ }^{15}$ Our study has been extended to nucleophilic substitution reactions of 2,4-dinitrophenyl X-substituted benzoates $\mathbf{1 a}(\mathrm{X}=4-\mathrm{MeO})$ and $\mathbf{1 c}\left(\mathrm{X}=4-\mathrm{NO}_{2}\right)$ with a series of Z-substituted pyridines whose basicity varies over $6 \mathrm{p} K_{\mathrm{a}}$ units (Scheme 1). The kinetic results for the reactions of $1 \mathbf{a}$ and $\mathbf{1 c}$ have been compared with those reported previously for the corresponding reactions of $\mathbf{1 b}$ to investigate the effect of non-

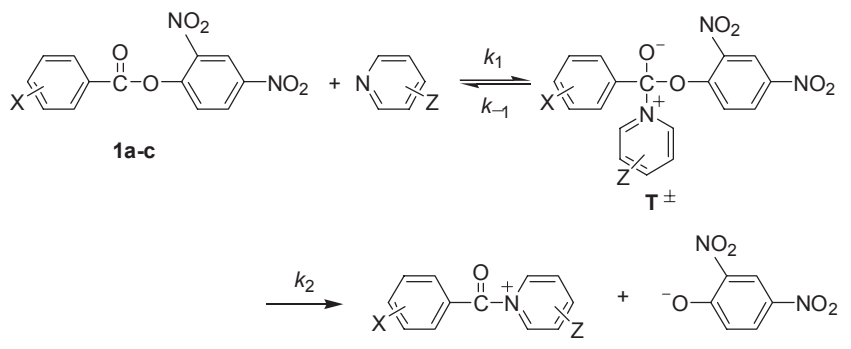

$\mathrm{X}=4-\mathrm{MeO}(\mathbf{1 a}), \mathrm{H}(\mathbf{1} \mathbf{b}), 4-\mathrm{NO}_{2}(\mathbf{1 c})$

$\mathrm{Z}=\mathrm{H}, 3-\mathrm{Me}, 4-\mathrm{Me}, 3,4-\mathrm{Me}_{2}, 4-\mathrm{NH}_{2}, 4-\mathrm{NMe}_{2}, 4-\mathrm{O}^{-}$

Scheme 1 
leaving-group substituents on mechanism including $\mathrm{p} K_{\mathrm{a}}^{\mathrm{o}}$ and the $k_{2} / k_{-1}$ ratio. To give more credence to the kinetic study, theoretical calculations have also been carried out.

\section{Results and Discussion}

All reactions obeyed pseudo-first-order kinetics. Pseudo-firstorder rate constants $\left(k_{\mathrm{obsd}}\right)$ were determined from the equation $\ln \left(A \infty-A_{t}\right)=-k_{\text {obsd }} t+C$. The plots of $k_{\text {obsd }} v s$. pyridine concentration were linear passing through the origin, indicating that the contribution of $\mathrm{H}_{2} \mathrm{O}$ and/or $\mathrm{OH}^{-}$from hydrolysis of pyridines to $k_{\text {obsd }}$ is negligible. Thus, the rate law is given by eq. (1), in which [S] and [Pyr] represent the concentration of the substrate and pyridine, respectively. The second-order rate constants $\left(k_{\mathrm{N}}\right)$ were determined from the slope of linear plots of $k_{\text {obsd }} v s$. [Pyr] and are summarized in Table 1 . From replicate runs, it was estimated that the uncertainty in the $k_{\mathrm{N}}$ values is less than $\pm 3 \%$.

$$
\text { Rate }=k_{\mathrm{obsd}}[\mathrm{S}] \text {, where } k_{\mathrm{obsd}}=k_{\mathrm{N}}[\mathrm{Pyr}]
$$

Effect of pyridine basicity on reactivity and mechanism. As shown in Table 1 , the second-order rate constant $\left(k_{\mathrm{N}}\right)$ for reactions of 1a-c increases as the basicity of the incoming pyridine increases, e.g., the $k_{\mathrm{N}}$ value for the reactions of $1 \mathbf{a}(\mathrm{X}=4-\mathrm{MeO})$ increases from $2.31 \times 10^{-3} \mathrm{M}^{-1} \mathrm{~s}^{-1}$ to 5.97 and $154 \mathrm{M}^{-1} \mathrm{~s}^{-1}$ as the $\mathrm{p} K_{\mathrm{a}}$ of the conjugate acid of pyridines increases from 4.73 to 8.93 and 11.30, in turn. Similar results are shown for the corresponding reactions of $\mathbf{1 b}(\mathrm{X}=\mathrm{H})$ and $\mathbf{1 c}\left(\mathrm{X}=4-\mathrm{NO}_{2}\right)$ although these substrates are more reactive than $\mathbf{1 a}$ toward all the pyridines studied.

The effect of pyridine basicity on reactivity is illustrated in Figure 1. The Brønsted-type plots exhibit downward curvature in all cases. Such curved Brønsted-type plots are typical for reactions reported to proceed through a stepwise mechanism with a change in RDS. In fact, the nonlinear Brønsted-type plot for the reaction of $\mathbf{1 b}$ has been reported as evidence for a change in RDS. Thus, one can suggest that pyridinolysis of 1a and 1c proceeds also through a stepwise mechanism with a change in RDS.

Table 1. Summary of second-order rate constant $k_{\mathrm{N}}$ for reactions of 2,4-dinitrophenyl X-substituted benzoates (1a-c) with Z-substituted pyridines in $80 \mathrm{~mol} \% \mathrm{H}_{2} \mathrm{O} / 20 \mathrm{~mol} \%$ DMSO at $25.0 \pm 0.1{ }^{\circ} \mathrm{C}^{a}$

\begin{tabular}{|c|c|c|c|c|}
\hline \multirow[b]{2}{*}{ Z } & \multirow[b]{2}{*}{$\mathrm{p} K_{\mathrm{a}}^{\mathrm{PyrH}^{+}}$} & \multicolumn{3}{|c|}{$k_{\mathrm{N}} / \mathrm{M}^{-1} \mathrm{~s}^{-1}$} \\
\hline & & $\begin{array}{c}\mathbf{1 a} \\
(\mathrm{X}=4-\mathrm{MeO})\end{array}$ & $\begin{array}{c}\mathbf{1 b} \\
(\mathrm{X}=\mathrm{H})\end{array}$ & $\begin{array}{c}\mathbf{1 c} \\
\left(\mathrm{X}=4-\mathrm{NO}_{2}\right)\end{array}$ \\
\hline 1. $\mathrm{H}$ & 4.73 & $2.31 \times 10^{-3}$ & $8.61 \times 10^{-3}$ & $6.14 \times 10^{-2}$ \\
\hline 2. 3-Me & 5.09 & $3.65 \times 10^{-3}$ & $1.67 \times 10^{-2}$ & $1.30 \times 10^{-1}$ \\
\hline 3. $4-\mathrm{Me}$ & 5.53 & $9.99 \times 10^{-3}$ & $4.69 \times 10^{-2}$ & $3.36 \times 10^{-1}$ \\
\hline 4. $3,4-\mathrm{Me}_{2}$ & 5.78 & $1.77 \times 10^{-2}$ & $7.25 \times 10^{-2}$ & $7.13 \times 10^{-1}$ \\
\hline 5. $4-\mathrm{NH}_{2}$ & 8.93 & 5.97 & 32.0 & 446 \\
\hline 6. $4-\mathrm{NMe}_{2}$ & 9.12 & 9.57 & 43.0 & 715 \\
\hline 7. $4-\mathrm{O}^{-}$ & 11.30 & 154 & 822 & 13600 \\
\hline
\end{tabular}

${ }^{a}$ The $\mathrm{p} K_{\mathrm{a}}$ of conjugate acids of pyridines and $k_{\mathrm{N}}$ values for reactions of $\mathbf{1 b}$ were taken from ref. 15 .
The nonlinear Brønsted-type plots shown in Figure 1 have been analyzed on the basis of the mechanism proposed in Scheme 1 using a semiempirical equation eq. (2). ${ }^{4,16}$ The parameters $\beta_{1}$ and $\beta_{2}$ represent the slope of the Brønsted-type plots in Figure 1 for the reactions with strongly basic and weakly basic pyridines, respectively, and $k_{\mathrm{N}}{ }^{\mathrm{o}}$ refers to the $k_{\mathrm{N}}$ value at $\mathrm{p} K_{\mathrm{a}}{ }^{\mathrm{o}}$, where $k_{2} / k_{-1}=1$.

$$
\begin{aligned}
& \log \left(k_{\mathrm{N}} / k_{\mathrm{N}}^{\mathrm{o}}\right)=\beta_{2}\left(\mathrm{p} K_{\mathrm{a}}-\mathrm{p} K_{\mathrm{a}}^{\mathrm{o}}\right)-\log (1+\alpha) / 2 \\
& \text { where } \log \alpha=\left(\beta_{2}-\beta_{1}\right)\left(\mathrm{p} K_{\mathrm{a}}-\mathrm{p} K_{\mathrm{a}}^{\mathrm{o}}\right)
\end{aligned}
$$

The parameters $\beta_{1}, \beta_{2}$ and $\mathrm{p} K_{\mathrm{a}}^{\mathrm{o}}$ values are shown in Figure 1 . It is noted that $\beta_{1}$ and $\beta_{2}$ increase as the substituent $\mathrm{X}$ in the benzoyl moiety changes from an EDG to an EWG, i.e., as X changes from 4-MeO to $\mathrm{H}$ and $4-\mathrm{NO}_{2}, \beta_{1}$ increases from 0.38 to 0.40 and 0.46 , respectively while $\beta_{2}$ increases from 0.89 to 0.90 and 0.96 , in turn. However, the $\mathrm{p} K_{\mathrm{a}}^{\mathrm{o}}$ value has been determined to be 9.5 regardless of the electronic nature of substituent $\mathrm{X}$ in the benzoyl moiety. This contrasts to the findings by Gresser and Jencks ${ }^{4}$ and by Castro et al ${ }^{5,6}$ that changing the substituent in the nonleaving group from an EDG to an EWG increases $\mathrm{p} K_{\mathrm{a}}^{\mathrm{o}}$ by decreasing the $k_{2} / k_{-1}$ ratio for aminolysis of esters. However, the current result is consistent with our previous conclusion that the $\mathrm{p} K_{\mathrm{a}}^{\mathrm{o}}$ and $k_{2} / k_{-1}$ ratio are not influenced by the electronic nature of the substituent $\mathrm{X}$ in the nonleaving group. $3,7 \mathrm{a}$

Dissection of $\boldsymbol{k}_{\mathrm{N}}$ into microscopic rate constants. To examine the above argument that the substituent $\mathrm{X}$ does not influence the $k_{2} / k_{-1}$ ratio, the $k_{\mathrm{N}}$ values have been dissected into the microscopic rate constants (i.e., $k_{1}$ and $k_{2} / k_{-1}$ ratio) associated with the reactions of $1 \mathbf{a}-\mathbf{c}$. The $k_{2} / k_{-1}$ ratio has been calculated from eq. (3) ${ }^{16}$ using the $\beta_{1}, \beta_{2}$ and $\mathrm{p} K_{\mathrm{a}}{ }^{\mathrm{o}}$ values determined above. The $k_{1}$ values have been calculated from eq. (4) using the $k_{\mathrm{N}}$ values in Table 1 and the $k_{2} / k_{-1}$ ratios calculated above. The $k_{1}$ and

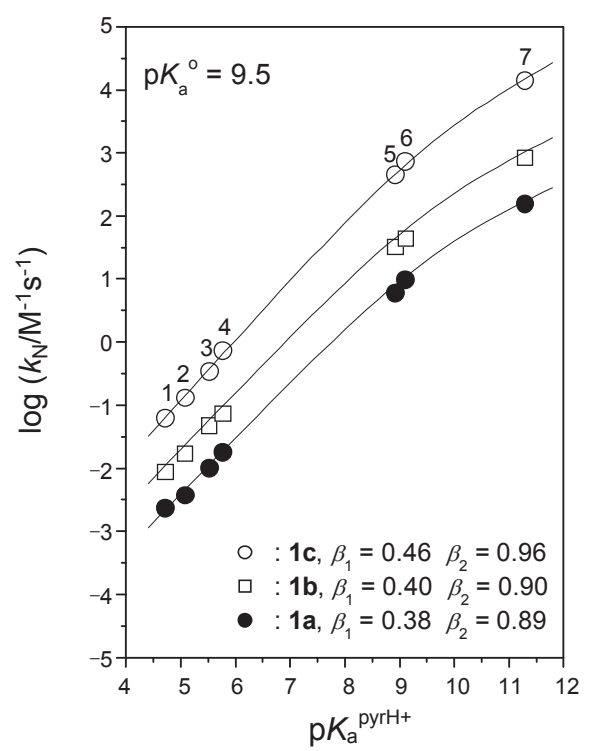

Figure 1. Brønsted-type plots for reactions of 2,4-dinitrophenyl X-substituted benzoates $\mathbf{1} \mathbf{a}(\mathrm{X}=4-\mathrm{MeO}), \mathbf{1} \mathbf{b}(\mathrm{X}=\mathrm{H})$, and $\mathbf{1} \mathbf{c}\left(\mathrm{X}=4-\mathrm{NO}_{2}\right)$ with Z-substituted pyridines in $80 \mathrm{~mol} \% \mathrm{H}_{2} \mathrm{O} / 20 \mathrm{~mol} \% \mathrm{DMSO}$ at $25.0 \pm 0.1{ }^{\circ} \mathrm{C}$. The identity of numbers is given in Table 1 . 
Table 2. Summary of microscopic rate constants for reactions of 2,4-dinitrophenyl X-substituted benzoates 1a-c with Z-substituted pyridines in $80 \mathrm{~mol} \% \mathrm{H}_{2} \mathrm{O} / 20 \mathrm{~mol} \% \mathrm{DMSO}$ at $25.0 \pm 0.1{ }^{\circ} \mathrm{C}$

\begin{tabular}{|c|c|c|c|c|c|c|c|}
\hline \multirow{2}{*}{$\mathrm{Z}$} & \multirow{2}{*}{$\mathrm{p} K_{\mathrm{a}}$} & \multicolumn{2}{|c|}{$\mathbf{1 a}(\mathrm{X}=4-\mathrm{MeO})$} & \multicolumn{2}{|c|}{$\mathbf{1 b}(\mathrm{X}=\mathrm{H})^{a}$} & \multicolumn{2}{|c|}{$\mathbf{1 c}\left(\mathrm{X}=4-\mathrm{NO}_{2}\right)$} \\
\hline & & $k_{1} / \mathrm{M}^{-1} \mathrm{~s}^{-1}$ & $k_{2} / k_{-1}$ & $k_{1} / \mathrm{M}^{-1} \mathrm{~s}^{-1}$ & $k_{2} / k_{-1}$ & $k_{1} / \mathrm{M}^{-1} \mathrm{~s}^{-1}$ & $k_{2} / k_{-1}$ \\
\hline 1. $\mathrm{H}$ & 4.73 & 0.628 & $3.69 \times 10^{-3}$ & 2.10 & $4.12 \times 10^{-3}$ & 15.0 & $4.12 \times 10^{-3}$ \\
\hline 2. $3-\mathrm{Me}$ & 5.09 & 0.651 & $5.64 \times 10^{-3}$ & 2.69 & $6.24 \times 10^{-3}$ & 21.0 & $6.24 \times 10^{-3}$ \\
\hline 3. $4-\mathrm{Me}$ & 5.53 & 1.07 & $9.45 \times 10^{-3}$ & 4.58 & $1.04 \times 10^{-2}$ & 32.8 & $1.04 \times 10^{-2}$ \\
\hline 4. $3,4-\mathrm{Me}_{2}$ & 5.78 & 1.41 & $1.27 \times 10^{-2}$ & 5.32 & $1.38 \times 10^{-2}$ & 52.4 & $1.38 \times 10^{-2}$ \\
\hline 5. $4-\mathrm{NH}_{2}$ & 8.93 & 17.6 & $5.12 \times 10^{-1}$ & 93.7 & $5.19 \times 10^{-1}$ & 1310 & $5.19 \times 10^{-1}$ \\
\hline 6. 4- $\mathrm{NMe}_{2}$ & 9.12 & 24.6 & $6.40 \times 10^{-1}$ & 110 & $6.46 \times 10^{-1}$ & 1820 & $6.46 \times 10^{-1}$ \\
\hline 7. $4-\mathrm{O}^{-}$ & 11.30 & 173 & 8.28 & 925 & 7.94 & 15300 & 7.94 \\
\hline
\end{tabular}

${ }^{a}$ Data for the reactions of $\mathbf{1 b}$ were taken from ref. 15 .

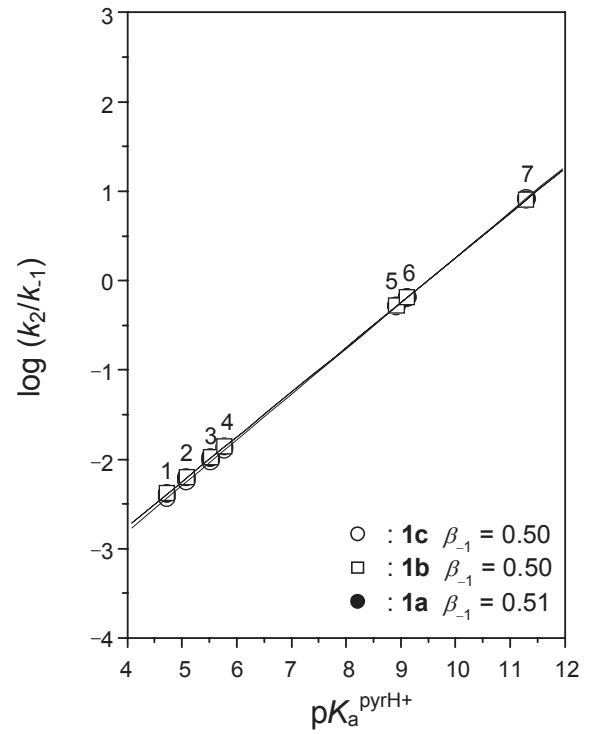

Figure 2. Plots of $\log k_{2} / k_{-1} v s$. $\mathrm{p} K_{\mathrm{a}}$ of conjugate acids of pyridines for reactions of 2,4-dinitrophenyl $\mathrm{X}$-substituted benzoates $\mathbf{1 a}(\mathrm{X}=4-\mathrm{MeO})$, $\mathbf{1 b}(\mathrm{X}=\mathrm{H})$, and $\mathbf{1 c}\left(\mathrm{X}=4-\mathrm{NO}_{2}\right)$ with $\mathrm{Z}$-substituted pyridines in 80 $\mathrm{mol} \% \mathrm{H}_{2} \mathrm{O} / 20 \mathrm{~mol} \% \mathrm{DMSO}$ at $25.0 \pm 0.1{ }^{\circ} \mathrm{C}$. The identity of numbers is given in Table 2 .

$k_{2} / k_{-1}$ ratios calculated in this way are summarized in Table 2.

$$
\begin{aligned}
& \left(\log k_{2} / k_{-1}\right)=\left(\beta_{2}-\beta_{1}\right)\left(\mathrm{p} K_{\mathrm{a}}-\mathrm{p} K_{\mathrm{a}}^{\mathrm{o}}\right) \\
& k_{\mathrm{N}}=k_{1} k_{2} /\left(k_{-1}+k_{2}\right)=k_{1} /\left(k_{-1} / k_{2}+1\right)
\end{aligned}
$$

As shown in Table 2, $k_{1}$ increases as the pyridine becomes more basic or as the substituent $X$ changes from an EDG to an EWG. The $k_{2} / k_{-1}$ ratio also increases as the basicity of pyridines increases. However, it is noted that the $k_{2} / k_{-1}$ ratio for a given pyridine remains nearly constant upon changing the substituent $\mathrm{X}$ from $4-\mathrm{MeO}$ to $\mathrm{H}$ and $4-\mathrm{NO}_{2}$.

The effect of substituent $\mathrm{X}$ and pyridine basicity on the $k_{2} / k_{-1}$ ratio is illustrated in Figure 2. One can see that the $k_{2} / k_{-1}$ ratio increases linearly with increasing pyridine basicity. However, the $k_{2} / k_{-1}$ ratios for the reactions of substrates $\mathbf{1 a - c}$ are almost identical for a given pyridine. This is consistent with our previous report that the electronic nature of the substituent $\mathrm{X}$ in the

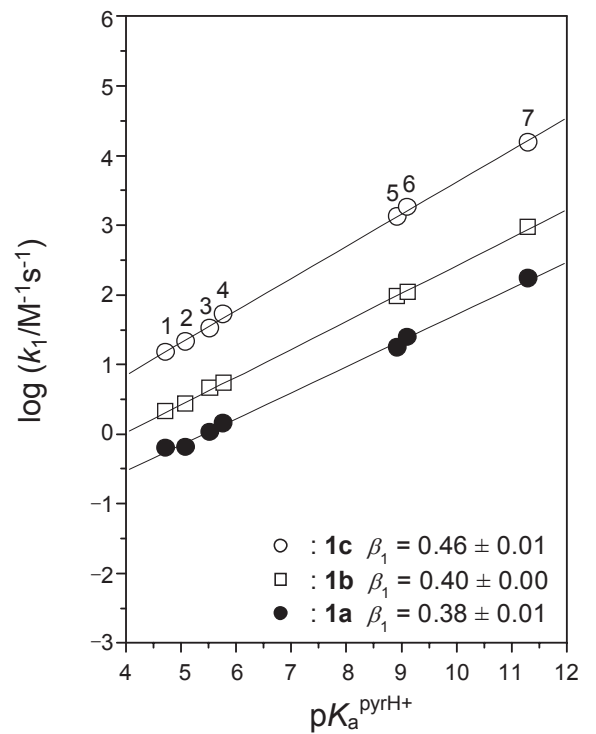

Figure 3. Plots of $\log k_{1} v s . \mathrm{p} K_{\mathrm{a}}^{\mathrm{PyrH}+}$ for reactions of 2,4-dinitrophenyl $\mathrm{X}$-substituted benzoates $\mathbf{1 a}(\mathrm{X}=4-\mathrm{MeO}), \mathbf{1 b}(\mathrm{X}=\mathrm{H})$, and $\mathbf{1 c}$ $\left(\mathrm{X}=4-\mathrm{NO}_{2}\right)$ with Z-substituted pyridines in $80 \mathrm{~mol} \% \mathrm{H}_{2} \mathrm{O} / 20 \mathrm{~mol} \%$ DMSO at $25.0 \pm 0.1{ }^{\circ} \mathrm{C}$. The identity of numbers is given in Table 2 .

nonleaving group does not influence the $k_{2} / k_{-1}$ ratio for pyridinolysis of $O$-4-dinitrophenyl X-substituted thionobenzoates ${ }^{3}$ and aminolysis of 2,4-dinitrophenyl X-substituted benzenesulfonates. $^{7 \mathrm{a}}$

The effect of pyridine basicity on $k_{1}$ is illustrated in Figure 3. The Brønsted-type plots are linear with increasing $\beta_{1}$ as the substituent $\mathrm{X}$ changes from an EDG to an EWG, i.e., $\beta_{1}=0.38$, 0.40 and 0.46 for the reactions of $\mathbf{1 a}, \mathbf{1 b}$ and $\mathbf{1 c}$, in turn. The $k_{1}$ value also increases as the substituent $\mathrm{X}$ changes from 4-MeO to $\mathrm{H}$ and $4-\mathrm{NO}_{2}$, which is in contrast to the result showing that the $k_{2} / k_{-1}$ ratio is independent of the nature of substituent $\mathrm{X}$ (Figure 2).

Calculations of bond lengths at MPW1K/6-31+G* level. To support the experimental results, we have theoretically calculated the bond lengths $a$ and $b$ in intermediate 2 for reactions of 1a-c with dimethylamine in $\mathrm{H}_{2} \mathrm{O}$. Here $a$ and $b$ represent the bond lengths between the central carbon and the oxygen in the leaving phenoxide, and between the central carbon and the 
Table 3. Summary of calculated bond lengths $a$ and $b$ in intermediate 2 for reactions of 2,4-dinitrophenyl X-substituted benzoates with dimethylamine in $\mathrm{H}_{2} \mathrm{O}$

\begin{tabular}{lccc}
\hline \multicolumn{1}{c}{$\mathrm{X}$} & $a / \AA$ & $b / \AA$ & $a / b$ \\
\hline $\mathbf{1 a}, 4-\mathrm{MeO}$ & 1.505 & 1.616 & 0.931 \\
$\mathbf{1 b}, \mathrm{H}$ & 1.503 & 1.611 & 0.933 \\
$\mathbf{1 c}, 4-\mathrm{NO}_{2}$ & 1.493 & 1.604 & 0.931 \\
\hline
\end{tabular}

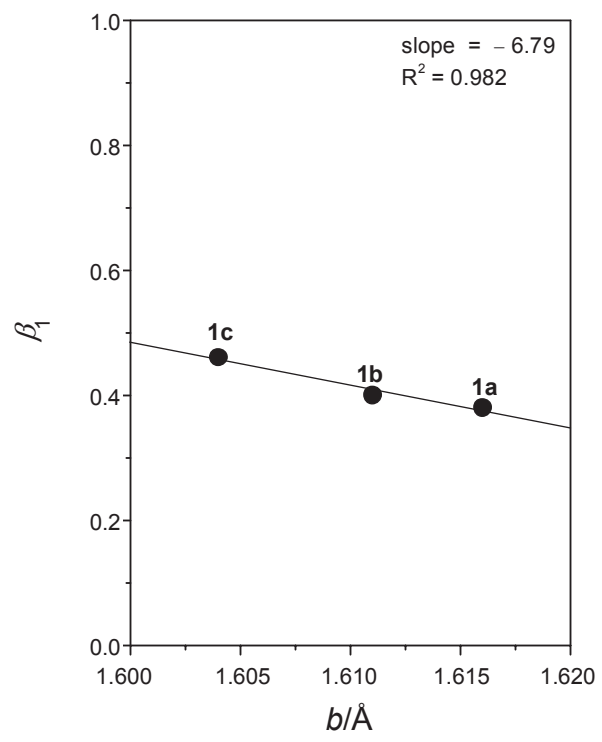

Figure 4. Plot showing a linear relationship between $\beta_{1}$ and the C-N bond length $b$ for pyridinolysis of 2,4-dinitrophenyl X-substituted benzoates 1a-c.

nitrogen in the aminium moiety of $\mathbf{2}$, respectively.

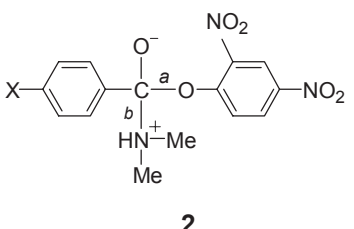

The results of our theoretical calculations at MPW1K/6-31+ $\mathrm{G}^{*}$ level are summarized in Table 4 . It is seen that the $\mathrm{C}-\mathrm{O}$ bond length $a$ decreases as substituent $\mathrm{X}$ changes from 4-MeO to $\mathrm{H}$ or 4- $\mathrm{NO}_{2}$, which appears to be consistent with the conclusion drawn by Gresser and Jencks, ${ }^{4}$ and by Castro et al. ${ }^{5,6}$ that an EWG decreases the rate of leaving-group departure (i.e., $k_{2}$ ). However, the C-N bond length $b$ also decreases as the substituent $\mathrm{X}$ changes from an EDG to an EWG. Consequently, the $a / b$ ratio is not influenced by the electronic nature of the substituent X (Table 3).

Since the transition state for the current reactions would be similar to intermediate 2 on the basis of the Hammond postulate, ${ }^{17}$ one might expect that the $a / b$ ratio corresponds to the $k_{2} / k_{-1}$ ratio. Thus, the fact that the $a / b$ ratio remains nearly constant upon changing the substituent $\mathrm{X}$ from $4-\mathrm{MeO}$ to $\mathrm{H}$ or $4-\mathrm{NO}_{2}$ is consistent with the preceding kinetic result that the $k_{2} / k_{-1}$ ratio is independent of the electronic nature of substituent X.

It is well known that the magnitude of $\beta_{1}$ represents the degree of bond formation between the nucleophile and the electrophile in transition state. Since a larger $\beta_{1}$ corresponds to a shorter $\mathrm{C}-\mathrm{N}$ bond length $b$, one might expect an inverse relationship between $\beta_{1}$ and $b$. In fact, Figure 4 shows good correlation between $\beta_{1}$ and $b$ with a negative slope.

\section{Conclusions}

The current study has allowed us to conclude the following: (1) Pyridinolysis of 2,4-dinitrophenyl X-substituted benzoates 1a-c proceeds through a stepwise mechanism with a change in $\mathrm{RDS}$ at $\mathrm{p} K_{\mathrm{a}}=9.5$. (2) The electronic nature of the substituent $\mathrm{X}$ influences $k_{1}$ but does not affect the $k_{2} / k_{-1}$ ratio. (3) The calculated bond lengths $a$ and $b$ decrease as the substituent $\mathrm{X}$ changes from an EDG to an EWG. Consequently, the $a / b$ ratio remains nearly constant upon changing the substituent $\mathrm{X}$ from 4- $\mathrm{MeO}$ to $\mathrm{H}$ or 4- $\mathrm{NO}_{2}$, which is consistent with the experimental result that the $k_{2} / k_{-1}$ ratio is not affected by the nature of the substituent $\mathrm{X}$.

\section{Experimental Section}

Materials. Compounds 1a and $1 \mathbf{c}$ were readily prepared from the reaction of X-substituted benzoyl chloride with 2,4-dinitrophenol in the presence of triethylamine in anhydrous ether as reported previously. ${ }^{10}$ Their purity was confirmed from melting point and spectral data such as ${ }^{1} \mathrm{H}$ NMR. Pyridines and other chemicals were of the highest quality available. Doubly glass distilled water was further boiled and cooled under nitrogen just before use.

Kinetics. The kinetic study was performed using a UV-vis spectrophotometer for slow reactions $\left(t_{1 / 2} \geq 10 \mathrm{~s}\right)$ or a stoppedflow spectrophotometer for fast reactions $\left(t_{1 / 2}<10 \mathrm{~s}\right)$ equipped with a constant temperature circulating bath to keep the reaction temperature at $25.0 \pm 0.1{ }^{\circ} \mathrm{C}$. All the reactions were carried out under pseudo-first-order conditions in which the pyridine concentration was at least 20 times greater than the substrate concentration. Due to low solubility of substrates $1 \mathbf{a}$ and $1 \mathbf{c}$ in pure water, reactions were carried out in $80 \mathrm{~mol} \% \mathrm{H}_{2} \mathrm{O} / 20 \mathrm{~mol} \%$ DMSO. Typically, the reaction was initiated by adding $5 \mu \mathrm{L}$ of a $0.01 \mathrm{M}$ of substrate stock solution in $\mathrm{MeCN}$ by a $10 \mu \mathrm{L}$ syringe to a $10 \mathrm{~mm} \mathrm{UV}$ cell containing $2.50 \mathrm{~mL}$ of the reaction medium and pyridine. The reactions were followed by monitoring the leaving 2,4-dinitrophenoxide at $410 \mathrm{~nm}$.

Product analysis. 2,4-Dinitrophenoxide was liberated quantitatively and identified as one of the reaction products by comparison of the UV-vis spectra after completing the reactions with those of authentic samples under the same kinetic conditions.

Calculations. The theoretical calculations were conducted at the Gaussian 03 program. ${ }^{18}$ The geometries of the intermediates in water were fully optimized at the MPW1K functional theory (6-31G and 6-31+G* $)^{19}$ using the Polarizable Continuum Model $(\mathrm{SCRF}-\mathrm{PCM})^{20}$ in which the molecular cavity used is the united atom topological model applied to radii optimized for the HF/ 6-31G(d) level theory. The stable structures were not observed 
in vacuum. Vibrational normal mode analyses were performed at the same level to ensure that each optimized structure was a true minimum on the potential energy surface, not an imaginary frequency. The geometries and energies of the optimized intermediates are given in Tables S1 and S2 in the Supporting Information.

Supporting Information. The optimized geometries and energies of the intermediates are available.

Acknowledgments. This research was supported by Basic Science Research Program through the National Research Foundation of Korea (NRF) funded by the Ministry of Education, Science and Technology (2009-0075488). E. H. Kim and L. R. Im are grateful for the BK 21 Scholarship. Grateful acknowledgement (I. H. Um) is also due to the JSPS program (L-08703).

\section{References}

1. (a) Jencks, W. P. Chem. Rev. 1985, 85, 511-527. (b) Castro, E. A. Chem. Rev. 1999, 99, 3505-3524. (c) Page, M. I.; Williams, A. Organic and Bio-organic Mechanisms; Longman: Singapore, 1997; Chapter 7.

2. (a) Castro, E. A.; Aliaga, M.; Santos, J. G. J. Org. Chem. 2005, 70, 2679-2685. (b) Castro, E. A.; Gazitua, M.; Santos, J. G. J. Org. Chem. 2005, 70, 8088-8092. (c) Castro, E. A.; Aliaga, M.; Santos, J. G. J. Org. Chem. 2004, 69, 6711-6714. (d) Castro, E. A.; Cubillos, M.; Santos, J. G. J. Org. Chem. 2004, 69, 4802-4807. (e) Castro, E. A.; Cubillos, M.; Aliaga, M.; Evangelisti, S.; Santos, J. G. J. Org. Chem. 2004, 69, 2411-2416.

3. Um, I. H.; Hwang, S. J.; Baek, M. H.; Kim, E. J. J. Org. Chem. 2006, 71, 9191-9197.

4. Gresser, M. J.; Jencks, W. P. J. Am. Chem. Soc. 1977, 99, 69706980.

5. (a) Castro, E. A.; Santander, C. L. J. Org. Chem. 1985, 50, 35953600. (b) Castro, E. A.; Valdivia, J. L. J. Org. Chem. 1986, 51, 1668-1672. (c) Castro, E. A.; Steinfort, G. B. J. Chem. Soc., Perkin Trans. 2 1983, 453-457.

6. (a) Castro, E. A.; Aguayo, R.; Bessolo, J.; Santos, J. G. J. Org. Chem. 2005, 70, 7788-7791. (b) Castro, E. A.; Aguayo, R.; Bessolo, J.; Santos, J. G. J. Org. Chem. 2005, 70, 3530-3536. (c) Castro, E. A.; Vivanco, M.; Aguayo, R.; Santos, J. G. J. Org. Chem. 2004, 69, 5399-5404. (d) Castro, E. A.; Aguayo, R.; Santos, J. G. J. Org. Chem. 2003, 68, 8157-8161.

7. (a) Um, I. H.; Hong, J. Y.; Seok, J. A. J. Org. Chem. 2005, 70, 1438-1444. (b) Um, I. H.; Chun, S. M.; Chae, O. M.; Fujio, M.; Tsuno, Y. J. Org. Chem. 2004, 69, 3166-3172. (c) Um, I. H.; Hong, J. Y.; Kim, J. J.; Chae, O. M.; Bae, S. K. J. Org. Chem. 2003, 68, $5180-5185$

8. (a) Oh, H. K.; Oh, J. Y.; Sung, D. D.; Lee, I. J. Org. Chem. 2005,
70, 5624-5629. (b) Lee, I.; Sung, D. D. Curr. Org. Chem. 2004, 8, 557-567. (c) Oh, H. K.; Park, J. E.; Sung, I.; Lee, D. D. J. Org. Chem. 2004, 69, 9285-9288. (d) Oh, H. K.; Ha, J. S.; Sung, D. D.; Lee, I. J. Org. Chem. 2004, 69, 8219-8223.

9. (a) Lumbiny, B. J.; Lee, H. W. Bull. Korean Chem. Soc. 2008, 29, 2065-2068. (b) Lumbiny, B. J.; Adhikar, K. K.; Lee, B. S.; Lee, H. W. Bull. Korean Chem. Soc. 2008, 29, 1769-1773. (c) Adhikary, K. K.; Lumbiny, B. J.; Kim, C. K.; Lee, H. W. Bull. Korean Chem. Soc. 2008, 29, 851-855.

10. (a) Menger, F. M.; Smith, J. H. J. Am. Chem. Soc. 1972, 94, 38243829. (b) Maude, A. B.; Williams, A. J. Chem. Soc. Perkin Trans. 2 1997, 179-183.

11. (a) Castro, E. A.; Acuña, M.; Soto, C.; Trujillo, C.; Vásquez, B.; Santos, J. G. J. Phys. Org. Chem. 2008, 21, 816-822. (b) Galabov, B.; Ilieva, S.; Hadjieva, B.; Atanasov, Y.; Schaefer, H. F., III. J. Phys. Chem. A 2008, 112, 6700-6707.

12. (a) Spillane, W. J.; McCaw, C. J. A. J. Phys. Org. Chem. 2006, 19, 512-517. (b) Spillane, W. J.; McGrath, P.; Brack, C.; O’Byrne, A. B. J. Org. Chem. 2001, 66, 6313-6316.

13. Tsang, W. Y.; Ahmed, N.; Hemming, K.; Page, M. I. J. Org. Chem. 2008, 73, 4504-4512.

14. (a) Um, I. H.; Jeon, J. E.; Seok, J. A. Chem. Eur. J. 2006, 12, 12371243. (b) Um, I. H.; Seok, J. A.; Kim, H. T.; Bae, S. K. J. Org. Chem. 2003, 68, 7742-7746.

15. Um, I. H.; Han, H. J.; Baek, M. H.; Bae, S. Y.J. Org. Chem. 2004, 69, 6365-6370.

16. (a) Castro, E. A.; Moodie, R. B. J. Chem. Soc. Chem. Commun. 1973, 828-829. (b) Castro, E. A.; Araneda, C. A.; Santos, J. G. J. Org. Chem. 1997, 62, 126-129.

17. Hammond, G. S. J. Am. Chem. Soc. 1955, 77, 334-338.

18. Gaussian 03 program, Revision D.01: Frisch, M. J.; Trucks, G. W.; Schlegel, H. B.; Scuseria, G. E.; Robb, M. A.; Cheeseman, J. R.; Montgomery, J. A., Jr.; Vreven, T.; Kudin, K. N.; Burant, J. C.; Millam, J. M.; Iyengar, S. S.; Tomasi, J.; Barone, V.; Mennucci, B.; Cossi, M.; Scalmani, G.; Rega, N.; Petersson, G. A.; Nakatsuji, H.; Hada, M.; Ehara, M.; Toyota, K.; Fukuda, R.; Hasegawa, J.; Ishida, M.; Nakajima, T.; Honda, Y.; Kitao, O.; Nakai, H.; Klene, M.; Li, X.; Knox, J. E.; Hratchian, H. P.; Cross, J. B.; Bakken, V.; Adamo, C.; Jaramillo, J.; Gomperts, R.; Stratmann, R. E.; Yazyev, O.; Austin, A. J.; Cammi, R.; Pomelli, C.; Ochterski, J. W.; Ayala, P. Y.; Morokuma, K.; Voth, G. A.; Salvador, P.; Dannenberg, J. J.; Zakrzewski, V. G.; Dapprich, S.; Daniels, A. D.; Strain, M. C.; Farkas, O.; Malick, D. K.; Rabuck, A. D.; Raghavachari, K.; Foresman, J. B.; Ortiz, J. V.; Cui, Q.; Baboul, A. G.; Clifford, S.; Cioslowski, J.; Stefanov, B. B.; Liu, G.; Liashenko, A.; Piskorz, P.; Komaromi, I.; Martin, R. L.; Fox, D. J.; Keith, T.; Al-Laham, M. A.; Peng, C. Y.; Nanayakkara, A.; Challacombe, M.; Gill, P. M. W.; Johnson, B.; Chen, W.; Wong, M. W.; Gonzalez C.; Pople, J. A. Gaussian, Inc., Wallingford CT, 2004.

19. Lynch, B. J.; Fast, P. L.; Harris, M.; Truhlar, D. G. J. Phys. Chem. A 2000, 104, 4811.

20. (a) Tomasi, J.; Persico, M. Chem. Rev. 1994, 94, 2027-2094. (b) Barone, V.; Cossi, M. J. Phys. Chem. A 1998, 102, 1995-2001. 